\title{
J.R.R. Tolkien's Portrayal of Femininity and Its Transformations in Subsequent Adaptations
}

\begin{abstract}
The aim of the following paper is to examine the portrayal of female characters and femininity in J.R.R. Tolkien's The Hobbit and The Lord of the Rings. Since Tolkien's heroines have been both praised and severely criticized, this paper will, first of all, investigate and recapitulate the arguments in favor and against Tolkien's depiction of women. Secondly, it will be argued that the ambiguity surrounding these fictional characters stems from the writer's private relationship with women. Finally, the paper will analyze how Tolkien's ambiguous female characters have fared in various adaptations of his works, particularly in the cinematic versions produced by Peter Jackson and in fan-made art.
\end{abstract}

Keywords: J.R.R. Tolkien; Middle-earth; females; femininity; adaptations.

J.R.R. Tolkien's portrayal of females and femininity-particularly in The Lord of the Rings (195455) - has long been the object of major criticism. Readers and academics have frequently objected to the scarcity of female heroes and their secondary roles in the narrative, and questioned the author's representations of femininity in general. ${ }^{12}$ After the release of Peter Jackson's movie adaptations of The Lord of the Rings (2001-2003) and The Hobbit (2012-2014), the debate over Tolkien's heroines gained an entirely new dimension, because the movies introduced several changes into the depiction of Middle-earth's women. The aim of this paper is, therefore, twofold: firstly, to evaluate the arguments in favor and against Tolkien's portrayal of women (a portrayal which is grounded in the writer's private relationships), and secondly, to analyze how Tolkien's female characters have fared in various adaptations. Some of these adaptations, particularly Jackson's movies, have been acknowledged worldwide and their imagery may now significantly influence the reception of Tolkien's books. Others, such as fan-made films and fan-fiction stories, are less known, yet they, too, are significant, because they reflect the fans' attitude to Tolkien's creation. The transformations which Tolkien's fiction, particularly its portrayal of women, has undergone in both

12 See Partridge 1983, Croft and Donovan 2015. 
groups of adaptations can be perceived as indicative of the postmodern audience's approach to the topics of gender relations and female empowerment.

Most of the critical comments concerning Tolkien's heroines are made in reference to The Lord of the Rings, not The Hobbit, for the simple reason that femininity is such a marginal issue in The Hobbit that it cannot even be decently criticized. After all, The Hobbit is the story of Bilbo Baggins' adventures with a group of dwarves. Females-be it hobbit, elf or dwarf ones-are almost non-existent and apparently not even needed since, in spite of their absence, the dragon is successfully killed, evil goblins defeated, and Bilbo delivered home more experienced. Femininity appears only at the distant margins of the main plot, e.g. as a brief remark about Thorin's sister (mother of Kili and Fili) and Bilbo's mother-Belladonna Took. Belladonna is described as "one of the three remarkable daughters of the Old Took" (Tolkien 1998: 13), and it is said that one of her ancestors had a "fairy wife" (1998: 13), which seems to explain why members of the family are more prone to adventures than other hobbits. Yet even for Belladonna everything changes after she marries Bungo Baggins.

The paragraph about Bilbo's mother is brief, yet it reveals a lot both about the heroes and the author. First of all, because of his mother's heritage, Bilbo is different from other hobbits, a "a bit queer" (Tolkien 1998: 13). In other words, Bilbo is special, and according to the patterns of fairy tales and fantasy fiction that immediately establishes him as the hero. Secondly, a shared trait of character suggests that a closer bond exists between Bilbo and his mother than between him and his father-which could be also said about Tolkien and his own mother, Mabel. Thirdly, the passage on Belladonna becomes a comment on the female nature in general. While masculinity is active, femininity is passive; "the famous Belladonna Took" (Tolkien 1998: 13) is just an exception to the rule, and even she settles down after marriage.

The absence, insignificance, and passivity of female characters-features discernable already in the short Hobbit-are the main claims leveled against The Lord of the Rings. Several examples from the text seem to firmly support these allegations. First and foremost, even though readers learn a bit about Rosie Cotton and Lobelia Sackville-Baggins, get distant glimpses of Arwen, and briefly encounter Galadriel and Éowyn, they cannot fail to notice that the world of Middle-earth is one of male dominance and patriarchal societies, in which women are scarcely present. ${ }^{13}$ John Miller (2003: 188) argues that even the War of the Ring is defined by masculinity because it "is a war of phallic edifices (contesting for, and threatened by, the power embodied in a symbol of the feminine, a ring)." ${ }^{14}$ Consequently, there are no female members in the Fellowship whose task it is to destroy the Ring. What is more, even outside the Fellowship, females are scarce. The trilogy shows one or two female representatives of every race, but in the case of ents, dwarves, and orcs there is not even a single one present. Moreover, except for the spider Shelob (and her mother Ungoliant that appears in The Silmarillion), there are no female enemies, as if "Tolkien was not comfortable

13 Gerard O’Connor goes as far as to accuse the trilogy of “institutional male chauvinism” (1973: 49).

14 These "phallic edifices” are, e.g. Minas Tirith, Minas Ithil, Orthanc, and the Tower of Barad-dur. 
conjoining the concepts female and enemy, as if it was not chivalrous" (Frederick and McBride 2001: 109). Finally, apart from Tom Bombadil, none of the major characters has a wife (Aragorn and Sam marry their beloveds only after the quest ends) or the wife is already dead (as in the case of Elrond, King Theoden, and Lord Denethor). With the exception of Aragorn and Sam, none of the heroes even mentions having a love interest.

This scarcity of male-female relationship in The Lord of the Rings can be explained, one the one hand, by the shortage of women characters. It is not surprising that with so few available women and with the world's safety at stake, romantic love becomes a marginal issue. Moreover, Brenda Partridge argues that even when there is some interaction between the opposite sexes, it "is for the most part stilted and distant" (1983: 183), and grounded in the ideals of chivalric romances and courtly love. As a result, sexual passion is almost non-existent. The female spider Shelob seems to be the sole reference to female sexuality, and not a very favorable one. Nick Otty argues that the description of Shelob contains reference to the female body made grotesque and disgusting, and that Shelob's attacks on Frodo and Sam "are also attempts upon their Hobbit virginities" (1983: 176). The positive male and female heroes generally seem prone to celibacy and become sexually active only within the bonds of matrimony. Marriage marks the end of adventures and the beginning of new social roles-for Sam as the leader of the hobbit community, and for Aragorn as the King of Gondor.

On the other hand, the male-female relationships are largely substituted by the feeling of male camaraderie. Whether it is the relationship between Frodo and Sam, Merry and Pippin, or Legolas and Gimli, Partridge is right to describe them as "intensely close and supportive" (1983: 183). In the face of Sam's fierce loyalty to Frodo, Merry's and Pippin's mutual care, and Legolas's and Gimli's fondness for each other, the relationships between Sam and Rosie or Aragorn and Arwen seem lukewarm at best. Partridge even argues that Sam's marriage is secondary to what he shares with Frodo: marriage "ensures that Sam, bereft of Frodo, will not be completely alone though the companionship it provides will never reach the depths of passion and spiritual intensity of the relationship of Sam and Frodo" (1983: 187). Candice Frederick and Sam McBride aptly summarize this scarcity of women and male-female relationship by arguing that "Middle-earth is very Inkling-like, in that while women exist in the world, they need not be given significant attention and can, if one is lucky, simply be avoided altogether" (2001: 108).

The female characters that do appear in Tolkien's fiction are criticized for their passivity, insignificance, and stereotypical roles. Kenneth McLeish likens them to cardboard figures (1983: 125) rather than plausible female characters. The delicate Rosie Cotton functions merely as the object of Sam's unrequited love, and then as his hard-earned prize. The other hobbit female, Lobelia Sackville-Baggins, represents the least favorite family member: a greedy relative whom it is best to avoid. Among the eleven women, both Arwen and Galadriel can be summed up as inspiration for male activity. The memory of Arwen-whom Gerard O'Connor calls "lovely, precious, and empty" (1973: 50)—is what keeps Aragorn going, whereas Galadriel's role is to support the Fellowship's quest with her generous gifts. Moreover, both Arwen and Galadriel are restrained 
by male power. Arwen's love for Aragorn is curbed by her father, whereas Galadriel is deferential towards her husband, though she is apparently more powerful. In the end, both elven women renounce whatever position they have because of men. Arwen sacrifices her immortality to be united with her beloved, while Galadriel has to sail to the West because she cannot live in the Age of Men. As for the human women, they, too, hardly transgress their stereotypical roles. Though by going to war Éowyn temporarily rebels against her society's norms, eventually she seems content with her place at Faramir's side. As Frederick and McBride argue, "Éowyn's healing is a victory, not only for Faramir but for their civilization; an unruly impulse to transcend prescribed gender roles has been successfully thwarted" (2001: 113). The other human woman, the old nurse Ioreth, is characterized mainly by her wisdom in healing and her talkativeness-two features frequently attributed to women. Finally, even the mysterious and apparently powerful Goldberry, Tom Bombadil's wife, withdraws from conversation and tends to her house duties when her husband gives advice to the hobbits. Though her presence is comforting and reassuring, she has little impact on the course of the adventure. Thus, Otty recapitulates women's roles in The Lord of the Rings in the following way:

The female Hobbits are either scolds or helpmeets of the most humble kind. The female Elves are devotional exemplars to be called on in emergency like the Virgin Mary. Amongst the humans Éowyn does get involved as a shield maiden disguised as a man and actually kills the Nazgul Lord. But she is an exception and is driven by her passion for Aragorn; otherwise the human women are healers and nurses in Gondor. (1983: 176)

In the face of such examples, it might seem viable to claim that while Tolkien's trilogy-with its complex history, languages, and landscapes-is a great work of fantastic subcreation, it severely diminishes women.

Yet this conclusion is true only if readers purposely overlook several examples of female empowerment and Tolkien's deep understanding of male-female relationship. These examples prove that Tolkien's heroines, despite their seeming withdrawal from direct combat and grand politics, are neither insignificant nor helpless. First of all, Lobelia's and Éowyn's deeds prove that in times of crisis women are able to defend their communities. The greedy and unsympathetic Lobelia surprises readers by her brave act of defiance: during an invasion of the Shire, she attacks one of Saruman's men with an umbrella, for which she is imprisoned. Likewise, Éowyn also intends to protect what she holds dear and rebels against her social position not because she wants a career as a swordswoman, but because she cannot ride to war like her kinsmen. The possibility that other women would like to join the battle cannot be ruled out by the argument that Tolkien does not mention any other female warriors. After all, similarly to his beloved sagas, Tolkien focuses on the fate of the mighty and powerful, not the common people (with the exception of the hobbits). Thus, Éowyn, given her royal status and skill in sword-fighting, is better prepared to transgress social boundaries than peasant women. It is also worth pointing out that after her participation in battle Éowyn is not punished for her transgression, but praised and respected-not a likely 
outcome if Middle-earth's society were truly so patriarchal as some critics assume. In the end, Éowyn does not insist on remaining a warrior, but redirects her courage and determination to her new social roles.

Secondly, heroines like Arwen, Galadriel, and Goldberry possess wisdom, power, and status which are not diminished by their respect for their husbands. Since Arwen and Galadriel are of great elven descent and Goldberry, ${ }^{15}$ "River-woman's daughter," possesses powers related to nature, all three transcend the boundaries between the material and spiritual world. According to Frederick and McBride, "Tolkien based more than one female character on his own veneration for the Virgin Mary, not the earthly, living mother of Jesus, but the distant yet matriarchal comfort of an interceding goddess" (2001: 107), hence the otherworldly nature of these heroines. Other biblical references in Tolkien's portrayal of women can also be identified. While commenting on the figures of Yavanna (the creator of the holy trees) and Varda (the creator of stars), Maureen Thum points out that these females

reverse the tale of Eve, whose weakness, passivity, and inability to resist temptation led to the Fall [...]. In Tolkien's tales, the destruction of Paradise is not brought about by a woman, but by a male figure [...]. Instead of playing a negative role, Yavanna and Varda are creators and givers of light and life. (2004: 235)

Consequently, the fact that the lore-wise Galadriel can humble herself for her husband proves how much she has changed since the times of her youth, when she rebelled against the Valar and was sent to Middle-earth as a penitent. Later in the story, it is Galadriel, not her husband, who is tempted by Frodo's offer of the One Ring and who successfully refuses the temptation. By doing so, Galadriel proves her wisdom and goodness, which remains in stark contrast with the behavior of some of the male heroes (e.g. Boromir). Similarly, the fact that Goldberry allows Tom Bombadil-the one who can make the One Ring disappear-to advise the hobbits is also a proof of her wisdom: she can recognize the limits of her own abilities and powers. Examples of empowered females are present also in Tolkien's other texts: Varda, known as Elbereth Gilthoniel, is worshipped by the elves as the Queen of Heaven; Melian the Maia is a wise and powerful ruler, and her daughter, Lúthien Tinúviel, not only saves her mortal beloved, Beren, but also manages to retrieve one of the Silmaril; Ancalimë, the only child of Aldarion and Erendis, becomes the heir of Númenor's throne and the island's first Queen. If all of these examples are taken into consideration, it becomes clear that in Tolkien's universe not only men, but women as well, hold royal power and are granted divine-like status.

What is more, though male-female relationship are scarce in The Lord of the Rings, the trilogy-in the story of the ents-emphasizes the value of marriage and provides advice on the proper relation-

15 Ann McCauley Basso argues that despite her brief appearance, Goldberry is a pivotal figure, because "both her character and her actions are thematically significant, providing symmetry with later events and characters, bridging the gap between the Anglo-Saxon, noble women and the rustic women of the Shire, and providing an Eve figure who parallels the Mary figure Galadriel." (2008: 137) Moreover, Taryne Jade Taylor argues that Goldberry's and Bombadil's first meeting in "The Adventures of Tom Bombadil” is Tolkien's reworking of an episode from Ovid's The Metamorphoses in which Pluto/Hades encounters Proserpina (2008: 148-149). 
ship between the spouses. In the distant past, the ents and the entwives parted their ways because the former wanted to take care of trees, while the latter preferred to plant gardens. Eventually, the two groups got separated for good and by the time of the War of the Ring the ents cannot find any trace of their mates, without whom they are doomed to extinction. Thus, the tale offers a clear warning: the lack of mutual understating between spouses can lead to separation that will be detrimental for both sides. A similar warning is voiced by the story "Aldarion and Erendis: The Mariner's Wife" from Tolkien's Unfinished Tales. Aldarion, the sixth King of Númenor and a great mariner, spends most of his time at sea. Because he makes Erendis, his wife, constantly wait for him and fear his next departure, the woman gradually grows bitter and spiteful. Eventually, their relationship completely deteriorates: Erendis cannot forgive her husband his love for the sea, and Aldarion does not wish to sacrifice his freedom for his wife. They destroy not only their own marriage, but also that of their daughter, Ancalimë, who is equally unable to form a healthy relationship with her husband. Thus, though marriage is only briefly mentioned in The Lord of the Rings-when Aragorn and Sam marry their beloveds-and seems hardly more than a clincher to the main plot, the fate of the ents and Aldarion demonstrate that Tolkien recognized martial happiness, based on the spouses' mutual understanding, as a prerequisite for personal happiness. Also the theme of romantic love, which is rather insignificant in The Lord of the Rings, reappears in Tolkien's other stories, and the tragic fate of Beren and Lúthien is one of the most compelling tales in Middle-earth's history.

If all of the above-mentioned examples are taken into consideration, the image of females and femininity present in Tolkien's works becomes an ambiguous one, including both passivity and empowerment. Such an ambiguous representation of women may be grounded in Tolkien's private experiences. On the one hand, his perception of women undoubtedly was shaped by the times he lived in. In the early and mid $20^{\text {th }}$ century women were still expected to concentrate on their family life and child raising; even though they received formal education, they were not encouraged to pursue a career after marriage. Such was the environment in which Tolkien grew up, and he did not expect his wife, Edith (a talented pianist), to do otherwise (Carpenter 1977: 156). What is more, as an academic, Tolkien was part of an environment dominated by men. The contact between male and female students was quite limited (Scull and Hammond, vol. 2, 2006: 1109), and women seldom participated in the intellectual discussions of some male clubs. In his own group, the Inklings, Tolkien was exposed not only to male camaraderie, but also to his friends' opinions about the 'proper' place of women. Partridge claims that C.S. Lewis was particularly strict on this issue: "It was an article of his faith that full intimacy with another man was impossible unless women were totally excluded. [...] Believing women's minds were not meant for logic or for great art it was his view that women had little to say that was worth listening to" (1983: 180). A quotation from Tolkien suggests that he might have shared that idea of women's intellectual inferiority or, at least, their dependency on men:

How quickly an intelligent woman can be taught, grasp the teacher's ideas, see his points-and how (with some exceptions) they can go no further, when they leave his hand, or when they cease to take a personal interest in him. It is their gift to be receptive, stimulated, fertilized (in many other matters than 
Furthermore, Tolkien's meetings with the Inklings seemed to cause tensions between him and Edith, who was not part of the group. Carpenter explains that Tolkien "perceived that his need of male friendship was not entirely compatible with married life. But he believed that this was one of the sad facts of a fallen world: and on the whole he thought that a man had a right to male pleasures, and should if necessary insist on them" (1977: 156). Finally, the passivity and withdrawal of Tolkien's heroines was probably inspired also by the writer's beloved myths and sagas, in which women seldom participated in battle and adventures; any romance was either framed within chivalric conventions or presented only superficially, without emotional or psychological depth. Partridge states that "the ancient, Norse and Christian mythologies in which he was immersed reinforced Tolkien's refusal [...] to accept the full and active participation of women in every area of life" (1983: 194).

On the other hand, Tolkien's biographies undermine the claim that he was a chauvinist and that he did not recognize women's achievements. On the contrary, Tolkien acknowledged and respected women who had the strength to follow their own convictions. The most influential example was probably Tolkien's mother, Mabel, who raised her sons after their father's premature death and who withstood her family's rejection after she had decided to convert to Roman Catholicism (Scull and Hammond, vol.2, 2006: 1107). Tolkien's own unrelenting faith in God was deeply grounded in his mother's convictions and her devotion to his and his brother's Catholic education. Mabel's sister, Jane Neave, was an example of an academically successful woman: she had a Bachelor of science degree and was a schoolteacher (Scull and Hammond, vol.2, 2006: 1108). What is more, Tolkien's only daughter, Priscilla, stated that her father always encouraged her education (in Scull and Hammond, vol.2, 2006: 1111). Thus, Scull and Hammond argue that

it is evident from his friendships and professional relationships, of which there were many, with female students and dons at Oxford, and from personal accounts by female friends, that Tolkien respected women no less than men for their talents, and that he welcomed their company. (vol.2, 2006: 1112)

What is more, Tolkien's relationship with his wife proves that he did not underestimate the importance of romantic love and marriage. Having met Edith Bratt as an adolescent, Tolkien had to endure long years of separation until he could officially propose-a restriction set by his guardian, Father Francis Morgan, after Tolkien had failed to get a scholarship to Oxford. Not surprisingly then, some of Tolkien's major fictional pairs are similarly tested by separation before they can fulfill their love: Beren and Lúthien (whose names are on the Tolkiens' grave), Aragorn and Arwen, Sam and Rosie. Moreover, though Tolkien was constantly occupied by academic life, intellectual disputes, and writing, his biographers believe that he deeply cared for Edith, particularly when her health deteriorated and he had to adjust his work to her needs (Scull and Hammond, vol.2, 2006: 1115). After all, marriage was for Tolkien not only a proper continuation of courtship, but also a vital element of a truly Christian life. If all of these examples of female passivity and empower- 
ment witnessed by Tolkien are taken into consideration, it is easy to understand why similarly ambiguous images appear in his fiction.

Such an ambiguous representation has posed a serious challenge for artists who wish to adapt Tolkien's Middle-earth in other forms of art. While some of these adaptations faithfully follow the original storyline, others make significant changes. Consequently, some of them retain female heroes in the background (if the females appear at all) ${ }^{16}$ apparently emphasizing their passivity and insignificance, whereas others alter the females and their roles in a striking way, perhaps to make them more appealing for the contemporary audience that expects powerful and well-defined female characters. Among the numerous adaptations of The Hobbit and The Lord of the Rings Peter Jackson's movie versions ${ }^{17}$ seem particularly significant, because they have rekindled people's interest in Middle-earth, made a lasting impression on their viewers, and inspired many to express their engagement with the fictional world and its characters through fan-art. As far as female characters are concerned, by removing, adding or altering the existing heroines, the producers introduced numerous changes into the portrayal of Middle-earth's women. ${ }^{18}$ All of these changes can, of course, be somehow justified. The Lord of the Rings, being a massive and detailed text, had to be converted into a script of reasonable length and clarity. At the expense of other scenes, significant characters had to be given enough screen time to become memorable and believable. Finally, events and relationships needed to be made obvious even for an audience not well versed in Tolkien's universe. Yet the resulting changes have received mixed criticism. While some viewers express their disappointment with the alterations, others agree that these alterations can be, nonetheless, reconciled with the spirit of Tolkien's vision.

Goldberry and Lobelia are examples of women who almost completely disappear from The Lord of the Rings screen version. The entire episode with Goldberry and Tom Bombadil was cut out for the sake of the movie's pace: the hobbits' respite at their house seems but a pause in the main quest, which the script could not afford to include. Thus, the hobbits from the movie never visit the benevolent pair, and a viewer less knowledgeable with the books will not even notice Goldberry's and Bombadil's absence. Similarly, the entire chapter of the Scouring of the Shire, the essential coda to the trilogy and the proof of the hobbits' spiritual growth, has also been removed in order to make room for other scenes. As a result, Lobelia, who briefly appears during Bilbo's birthday party episode, never gets the chance to defy Saruman's henchmen and show the better side of her personality. Though Jackson's movies generally make Tolkien females more active than they are in the books, the absence of Goldberry and Lobelia is a reduction of female energy in comparison to the original story.

16 For instance, Arwen does not appear either in Ralph Bakshi's animated adaptation of The Lord of the Rings (1978) or Rankin/Bass animation The Return of the King: A Story of the Hobbits (1980).

17 The Hobbit: An Unexpected Journey (2012), The Desolation of Smaug (2013), There and Back Again (2014). The Lord of the Rings: The Fellowship of the Ring (2001), The Two Towers (2002), The Return of the King (2003).

18 See David Mullich's “The Complete List of Film Changes for The Hobbit and The Lord of the Rings” available on The One Ring.com 
While Goldberry and Lobelia disappear, other females appear in both expected and unexpected places. The first example of additional female presence pertains to women in general, as members of Middle-earth's communities. While it is not surprising that in the movie versions women (hobbit, elven, and human) appear in the background of the main events, their presence is quite significant, because Tolkien's fans can finally see the women of Middle-earth and acknowledge their existence-something that is easily dismissed when the books concentrate on the male heroes and their rambling adventures.

While females as members of communities can be expected to appear, Galadriel (played by Cate Blanchett) makes a series of appearance that are inconsistent with the books. In The Lord of the Rings, Galadriel narrates the prologue opening the movie, which recapitulates the history of Middle-earth and the Ring. Though other narrators were considered (Frodo, Gandalf), Galadriel was eventually chosen either because her elven longevity establishes her as a witness of the related events or because the quality of Cate Blanchett's voice fits the narration so well. Regardless of the reasons, this act of narration puts Galadriel in a position of power and grants her more authority. In the case of The Hobbit, Galadriel suddenly makes an unexpected appearance in the movie adaptation, in the sub-plot about the Necromancer gathering his forces at Dol Guldur. Together with Gandalf, Elrond, and Saruman, she debates how to address the challenge of the Necromancer and provides emotional consolation to other characters. Therefore, the producers again established Galadriel, a female, as a major persona and a figure of power.

The most striking change in The Hobbit movie-as far as females are concerned-is the addition of Tauriel, a female Woodland Elf (played by Evangeline Lilly). Her presence is such a striking change for a few reasons. Firstly, Tauriel is not only a skilled warrior who does not hesitate to kill her enemies, but also the head of the Mirkwood Elven Guard, thus, she occupies a typically male position. Secondly, she is strong-willed and impulsive. Having learnt that Kili will soon die from a poisoned arrow, she leaves her kingdom without permission and pursues the dwarves. Thirdly, she is placed in a love triangle with Kili and Legolas. Tauriel's conversation with Kili and her frantic race to save him imply that she develops strong feelings towards the dwarf, despite their racial difference. The Battle of the Five Armies proves that Kili reciprocates her love. However, Jackson does not cross the line and ends the 'forbidden' romance by remaining faithful to the original storyline: Kili dies during the battle (which leaves Tauriel to grieve her lost love). All in all, by adding Galadriel's narration in The Lord of the Rings and her presence in The Hobbit, as well as by inventing Tauriel, the scriptwriters tipped the balance of male and female power in Middle-earth in favor of femininity. Yet while Galadriel's new roles and extended authority generally correspond to Tolkien's vision of her as a powerful elven woman, Tauriel and her complicated love life are undoubtedly more 'Jacksonian' than Tolkienian. ${ }^{19}$

19 The most hilarious fan-made critique of Tauriel, as well as of some other changes to the plot of The Hobbit, appears in the song "Who the "Ell is Tauriel" sung by The Esgaroth Three (available on YouTube). 
Apart from removing or adding female heroes, Jackson's movies have also introduced minor or major changes in the portrayal of Rosie Cotton, Éowyn, and Arwen. Rosie Cotton is shown working as a barmaid in one of the hobbit taverns. While in both the text and the movie Rosie (Sarah McLeod) exists solely for the purpose of being Sam's distant love and then his earned wife, Jackson's idea to turn her into a barmaid of a tavern which Sam frequently visits creates believable background for the hobbit's infatuation. Whether Tolkien would approve of this change remains a question, but such a minor alteration does not seem to disrupt the author's vision.

In the case of Éowyn (Miranda Otto), her cinematic version seems fairly close to Tolkien's vision: the princess of Rohan is both a feminine woman and a fearless defender of her kingdom. The changes which the scriptwriters permitted themselves to make introduce some light humor into Éowyn's character. In the original text, Éowyn is a tragic heroine since she has to passively observe her uncle's withering, suffer Grima's advances, overcome Aragorn's refusal to reciprocate her love, and ride to battle in disguise, before she finds happiness at Faramir's side. While all of this does take place in the movies, elements of humor added by the filmmakers introduce new traits into the princess's character. For instance, in one scene Éowyn offers Aragorn some self-made food. The food must be disgusting since the man tries to secretly throw it away, yet then he mercifully pretends (to the amusement of the audience) to be enjoying his meal. In another scene (at Helm's Deep), Éowyn talks with Gimli about dwarf women and their rumored beards. Inarguably, such scenes make Éowyn more likeable as a character. Nevertheless, while the princess might have wanted to make food for Aragorn to express her affection, her conversation with Gimli about the nature of dwarf women seems less legitimate according to Middleearth's standards.

The greatest changes appears in the portrayal of Arwen (Liv Tyler). In both the text and the movie Arwen is presented as a noble elven woman of great beauty and dignity. But while in the original text she appears for only a moment and even her marriage to Aragorn is mentioned in the Appendices, in Jackson's movies Arwen receives much more exposition. On top of that, she is presented as a fierce warrior and a figure of power. It is Arwen, not Glorfindel, that finds Aragorn and the hobbits in the wilderness, and rescues the wounded Frodo from the Black Riders. It is Arwen, not Elrond, who calls forth the flood at the Ford of Bruinen after she brandished her sword at them. ${ }^{20}$ What is more, the movies add scenes which emphasize Arwen and Aragorn's romantic relationship. In Rivendell, Arwen gives Aragorn an elven jewel called Evenstar as a token of her love; the jewel then reappears through the movies, giving the hero spiritual strength on his quest. In another scene, when Aragorn floats down the river after a battle, he is woken up by a spectral image of Arwen and her kiss. ${ }^{21}$ The film also highlights the difficulty of Arwen's decision about

20 At one point, the filmmakers even planned to have Arwen actively participate in the battle at Helm's Deep (West 2011: 234).

21 A similar scene appears in The Hunt for Gollum (2009), a non-profit, fan-made prequel to The Lord of the Rings, directed by Chris Bouchard. The movie follows Aragon (Adrian Webster) on his quest to capture Gollum. Arwen (Rita 
whether to choose love and mortality or accompany her father to the Undying Lands. All of these scenes required, of course, additional dialogue and events not described by Tolkien. Nevertheless, some critics claim that these additions fit Tolkien's overall vision and match the spirit of the books. For instance, by arguing that "Arwen's role is a logical extrapolation based on the actions of other Elven characters, a reflection of the past power of the Eldar in Middle-earth" (2004: 202), Cathy Akers-Jordan points out that Arwen's heroism in the first part of the movie is similar to that of her brave female ancestors-Lúthien, Idril, and Galadriel—and thus it can be easily reconciled with Tolkien's mythology. ${ }^{22}$ When commenting on Jackson's overall depiction of Tolkien's females, Thum adds that "[d]espite sometimes radical alterations in the text, [...] Jackson's re-creation remains true to the spirit of Tolkien's writings" (2004: 232), because Tolkien's women "are positive figures whose influence extends far beyond their often brief appearances in the pages of his writings, and Jackson's film reflects that fact" (2004: 254). It can be argued, therefore, that whether one perceives Jackson's rendering of Middle-earth women as either true to the original or not is grounded in Tolkien's own ambiguous portrayal of female characters. Readers who claim that in Tolkien's world women are passive and powerless will see the movie images as a distortion of the original. Yet readers who acknowledge Tolkien's subtle empowerment of female characters will contend that the movie images are Jackson's exploration of the same ideas.

A similar argument pertains to fan-made art. Today, fans frequently express their opinions by creating video clips, drawing, and stories about their favorite series and heroes. Their works often complement the assumed 'shortcomings' of the original text, explore the possibilities not fully developed in the text, or combine the original text with the artist's own ideas and inventions. The ways in which fan-art, particularly fan-made videos and fan-written stories, handle the topic of females and femininity in Middle-earth offer valuable glimpses into the audience's perception of gender relations in Middle-earth. ${ }^{23}$

Ramnani) does not appear in the movie directly, but only in the flashback of Aragorn's memories: she encourages him by reminding him that he is the heir of kings, and when he faints after a battle (because of a poisoned arrow), he has a vision of their meeting and a shared kiss. These scenes, like the ones created by Jackson, highlight Arwen's influence over Aragorn. It remains unknown whether Bouchard consciously emulated Jackson or whether Jackson's rendering of Arwen and Aragorn's relationship has become such an influence on other creators. The full movie is available at www.thehuntforgollum.com

22 Perhaps for a similar reason the authors of Born of Hope (2009) decided to show female warriors. Born of Hope is another non-profit movie, directed by Kate Madison. It tells the story of Aragorn's parents, Gilraen and Arathorn, and their fight to preserve the line of Isildur's heirs. Like The Lord of the Rings prologue, Born of Hope is narrated by a woman, Gilraen (Beth Aynsley). Like The Lord of the Rings, it shows women as warriors: Gilraen is ready to fight with orcs to protect her family, and she is aided by a skilful female Ranger, Elgarain (Kate Madison). In addition, romantic love is one of the main themes. Viewers observe how Gilrean and Arathorn fall in love, while Elgarain has to hide her own feeling for the man. This love triangle is clearly an emulation of the relationship between Arwen, Aragorn, and Éowyn. Though Elgarain is an original character created by the movie's authors, the influence of The Lord of the Rings is easily discernable.

23 For a detailed analysis of fan communities and their approaches to Middle-earth see Booker 2004. 
As far as video clips are concerned, fans of The Hobbit and The Lord of the Rings use images from Jackson's movies to comment on the cinematic adaptations and to construct alternative stories involving the cast of Middle-earth's heroes. It can be argued that clips devoted to Tolkien's female characters concentrate either on emphasizing their greatest qualities and deeds (thus continuing Jackson's work of strengthening female empowerment) or on exploring their love relationships. Thus, on the one hand, dozens of video clips with Éowyn praise her courage and recount her fight with the Nazgul; works with Arwen affirm her beauty and the magnitude of her sacrifice; Galadriel is shown as a woman of great power, while Tauriel is hailed as the beautiful and merciless warrior. On the other hand, numerous clips are devoted to these women's love interests. While some focus on the relationships present in the story (e.g. Éowyn's unrequited love for Aragorn and her meeting with Faramir, Aragorn's union with Arwen), others recombine various scenes (and add romantic or catchy pop music) to emphasize a different aspect of these relationships-e.g. a tense love triangle between Éowyn, Aragorn, and Arwen-or even entirely alternative pairings, e.g. Arwen and Legolas, Galadriel and Gandalf, etc. After the release of The Desolation of Smaug, several clips have focused on the implied love between Tauriel and Kili. Though both varieties of clips are amusing, the ones with alternative pairings transgress (or even violate) the original text in a more serious way that those which only strengthen the idea of female empowerment.

A similar transgression is the basis for many fan-written stories (called fanfiction). Fanfiction.net is one of the largest fanfiction-storing websites, and currently it contains thousands of The Hobbit- and The Lord of the Rings-related works. Like the video clips posted on YouTube, hundreds of these stories develop alternative pairings or explore the implications of the already existing relationships. Some examples include retellings of the meeting and courtship of Arwen's parents, and analyses of Arwen's insecurities in the face of her newly gained mortality. What is more, other fan-writers further tip the balance of female power in Middle-earth by introducing entirely original heroines. These new women explore the mysteries of Middle-earth, face the hardships of travel, do brave deeds of their own, and frequently pair up with one of the existing male characters. Interestingly, these new characters are not necessarily of Middle-earth origin: there is a separate group of stories that feature modern-day girls transported into Tolkien's realm. Such works concentrate on discovery, exploration, and humor stemming from the contrast between the modern girls' behavior and the dictates of Middle-earth. Regardless of the literary quality of such works, they express their authors' deep sentiment for Tolkien's realm and their need for strong, active, and well-defined female characters. Even though fan stories frequently deviate from the canonical text, they nonetheless involve the writers into their own little acts of sub-creation within the boundaries of Middle-earth and, therefore, keep the realm alive in their minds and hearts. Given all of the examples of female passivity and empowerment present in Tolkien's creation, it can be argued that the writer's ambiguous portrayal of females and femininity simply offers other artists (like Jackson) and aspiring fan-artists plenty of room for analysis and creative interpretation. 


\section{REFERENCES}

Akers-Jordan, Cathy. 2004. Fairy Princess or Tragic Heroine? The Metamorphosis of Arwen Undómiel in Peter Jackson's The Lord of the Rings Films. In: Janet Brennan Croft (ed.), Tolkien on Film: Essays on Peter Jackson's The Lord of the Rings, 195-213. Altadena, California: The Mythopoeic Press.

Basso, Ann McCauley. 2008. Fairy Lady Goldberry, Daughter of the River. Mythlore 27:1/2. 137146.

Booker, Susan. 2004. Tales Around the Internet Campfire: Fan Fiction in Tolkien's Universe. In: Janet Brennan Croft (ed.), Tolkien on Film: Essays on Peter Jackson's The Lord of the Rings, 259282. Altadena, California: The Mythopoeic Press.

Carpenter, Humphrey. 1977. J.R.R. Tolkien: A Biography. London: Allen \& Unwin.

Carpenter, Humphrey. 1978. The Inklings: C.S. Lewis, J.R.R. Tolkien, Charles Williams and their Friends. London: Allen \& Unwin.

Croft, Janet Brennan and Leslie A. Donovan (eds.) 2015. Perilous and Fair: Women in the Works and Life of J.R.R. Tolkien. Altadena: Mythopoeic Press.

Frederick, Candice and Sam McBride. 2001. Women Among the Inklings: Gender, C.S. Lewis, J.R.R. Tolkien, and Charles Williams. Westport: Greenwood Press.

McLeish, Kenneth. 1983. The Rippingest Yarn of All. In: Robert Giddings (ed.), J.R.R. Tolkien: This Far Land, 125-136. London: Vision and Barnes \& Noble.

Miller, John. 2003. The Hero and the Other: Alternative Masculinities and the 'Dominion of Men' in The Lord of the Rings. In: Susanne Fendler and Ulrike Horstmann (eds.), Images of Masculinity in Fantasy Fiction, 183-203. Lewiston, NY: Edwin Mellen Press.

Mullich, David. Date n/a. The Complete List of Film Changes for The Hobbit and The Lord of the Rings. http://www.theonering.com/complete-list-of-film-changes (13 December 2016).

O'Connor, Gerard. 1973. Why Tolkien's The Lord of the Rings Should Not be Popular Culture. Extrapolation: A Journal of Science Fiction and Fantasy, vol. 13, no. 1. 48-55.

Otty, Nick. 1983. The Structuralist's Guide to Middle-earth. In: Robert Giddings (ed.), J.R.R. Tolkien: This Far Land, 154-178. London: Vision and Barnes \& Noble.

Partridge, Brenda. 1983. No Sex Please-We're Hobbits: The Construction of Female Sexuality in The Lord of the Rings. In: Robert Giddings (ed.), J.R.R. Tolkien: This Far Land, 179-197. London: Vision and Barnes \& Noble.

Scull, Christina and Wayne G. Hammond. 2006. The J.R.R. Tolkien Companion \& Guide. Vols. 1 \& 2. London: HarperCollinsPublishers.

Taylor, Taryne Jade. 2008. Investigating the Role and Origin of Goldberry in Tolkien's Mythology. Mythlore 27:1/2. 147-156.

Thum, Maureen. 2004. The 'Sub-Subcreation' of Galadriel, Arwen, and Éowyn: Women of Power in Tolkien's and Jackson's The Lord of the Rings. In: Janet Brennan Croft (ed.), Tolkien on Film: Essays on Peter Jackson's The Lord of the Rings, 231-256. Altadena, California: The Mythopoeic Press. 
Tolkien, J.R.R. 1998. The Hobbit or There and Back Again. London: Collins Modern Classics. West, Richard C. 2011. Neither the Shadow nor the Twilight: The Love Story of Aragorn and Arwen in Literature and Film. In: Janice M. Bogstad and Philip E. Kaveny (eds.), Picturing Tolkien: Essays on Peter Jackson's The Lord of the Rings Film Trilogy, 227-237. Jefferson: McFarland. 